Article

\title{
Aza-Amino Acids Disrupt $\beta$-Sheet Secondary Structures
}

\author{
Michael A. McMechen ${ }^{\dagger}$, Evan L. Willis ${ }^{+}(\mathbb{D}$, Preston C. Gourville and Caroline Proulx *(D) \\ Department of Chemistry, North Carolina State University, Raleigh, NC 27695-8204, USA; \\ mamcmech@ncsu.edu (M.A.M.); elwilli5@ncsu.edu (E.L.W.); pcgourvi@ncsu.edu (P.C.G.) \\ * Correspondence: cproulx@ncsu.edu; Tel.: +1-919-515-9534 \\ + These authors contributed equally to this work.
}

Academic Editors: Henry Mosberg, Tomi Sawyer and Carrie Haskell-Luevano Received: 1 May 2019; Accepted: 17 May 2019; Published: 18 May 2019

\begin{abstract}
C} \alpha$ to $\mathrm{N}$ substitution in aza-amino acids imposes local conformational constraints, changes in hydrogen bonding properties, and leads to adaptive chirality at the nitrogen atom. These properties can be exploited in mimicry and stabilization of peptide secondary structures and self-assembly. Here, the effect of a single aza-amino acid incorporation located in the upper $\beta$-strand at a hydrogen-bonded (HB) site of a $\beta$-hairpin model peptide (H-Arg-Tyr-Val-Glu-Val-D-Pro-Gly-Orn-Lys-Ile-Leu-Gln- $\mathrm{NH}_{2}$ ) is reported. Specifically, analogs in which valine ${ }^{3}$ was substituted for aza-valine ${ }^{3}$ or aza-glycine ${ }^{3}$ were synthesized, and their $\beta$-hairpin stabilities were examined using Nuclear Magnetic Resonance (NMR) spectroscopy. The azapeptide analogs were found to destabilize $\beta$-hairpin formation compared to the parent peptide. The aza-valine ${ }^{3}$ residue was more disruptive of $\beta$-hairpin geometry than its aza-glycine ${ }^{3}$ counterpart.
\end{abstract}

Keywords: peptidomimetics; azapeptides; aza-amino acids; $\beta$-hairpin; $\beta$-sheet

\section{Introduction}

$\beta$-sheets are common protein secondary structures that are often involved in protein-protein interactions and protein aggregation [1,2]. To understand factors governing folding, stability, and molecular recognition events involving $\beta$-sheets, water soluble $\beta$-hairpin model systems that are partially folded have been developed, consisting of two antiparallel $\beta$-strands connected by a reverse turn unit [3]. In the pursuit of protein-protein interaction (PPI) inhibitors, $\beta$-strand and $\beta$-sheet peptidomimetics have been explored using a variety of unnatural scaffolds [4]. When mimicking $\beta$-strands in particular, the hydrogen bonding pattern of a natural peptide is ideally replicated by the artificial templates to maintain cross-strand interactions, yet surface exposed hydrogen bonding sites should be minimized to prevent uncontrolled aggregation, creating a so-called "blocking strand" [5-7]. Here, we describe the effect of a single $\mathrm{C} \alpha$ substitution for a nitrogen at the $\mathrm{Val}^{3}$ position of a model $\beta$-hairpin peptide. The aza-amino acid residue was envisioned to provide two distinct faces with divergent hydrogen bonding capabilities, while retaining side chain position and chemistry (Figure 1).

Aza-amino acids [8] have been used to promote $\beta$-turn secondary structures and hyperstable collagen peptide mimics $[9,10]$ via a combination of hydrogen bonding and backbone dihedral angle modulation. Their effect on $\beta$-hairpin stability has yet to be quantified within $\beta$-strand regions. In aza-amino acids, perpendicular lone pair orientation between adjacent nitrogen and urea planarity typically reinforce backbone dihedral angles that fall within the range of $\beta$-turns and polyproline type II secondary structures [8]. Although this may prevent adoption of extended $\beta$-strand geometry [11], computational studies have set the energy barrier for rotation from the twisted conformer $\left(\varphi=90^{\circ}\right)$ to the extended conformer $\left(\varphi=180^{\circ}\right)$ to be $<1 \mathrm{kcal} / \mathrm{mol}$ within 1,2-diformylhydrazine in the $Z, Z$ configuration as an azaGly model [12]. Two favorable intramolecular hydrogen bonds are proposed to stabilize the $180^{\circ}$ 
orientation. Although addition of side chain chemistry in aza-amino acids removes an intramolecular hydrogen bond with a neighboring residue, cross-strand hydrogen bonding and side chain; side chain interactions in a $\beta$-hairpin may provide added stability to the extended conformer. Substitution of $\mathrm{Val}^{3}$ for aza-valine ${ }^{3}$ was thus examined in a well-studied $\beta$-hairpin model system for which Nuclear Magnetic Resonance (NMR)-based quantification of $\beta$-hairpin folding have been established, first reported by Gellman et al. [13,14]: H-Arg-Tyr-Val-Glu-Val-o-Pro-Gly-Orn-Lys-Ile-Leu-Gln- $\mathrm{NH}_{2}$ (1a). Valine $^{3}$ is situated in the middle of the upper $\beta$-strand at a hydrogen bonded (HB) site (Figure 2, in blue), equally removed from the D-Pro-Gly turn region and the $N$-terminus. In addition to azaVal ${ }^{3}$ analog $\mathbf{1 b}$, D-Val ${ }^{3}$ control 1c, azaGly ${ }^{3}$ analog 1d, and previously described [14] positive control cyclic peptide 1e, and negative control L-Pro ${ }^{6}-\mathrm{Gly}^{7}$ peptide 1f, all were synthesized and studied (Figure 2). Since the first incorporation of azaVal to give an azapeptide angiotensin analog [15], considerable interest has been generated in the synthesis and conformational properties of this aza-amino acid.

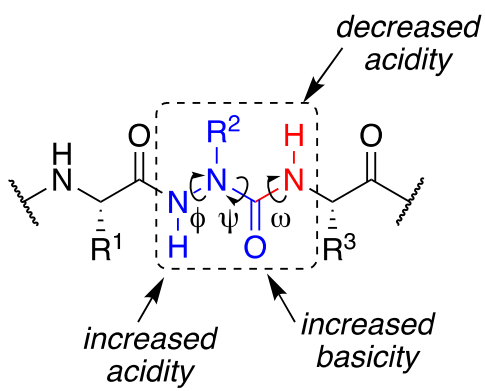

Figure 1. Aza-amino acid (in blue) creates one face with increased hydrogen bonding properties and one with reduced hydrogen bonding capacity.

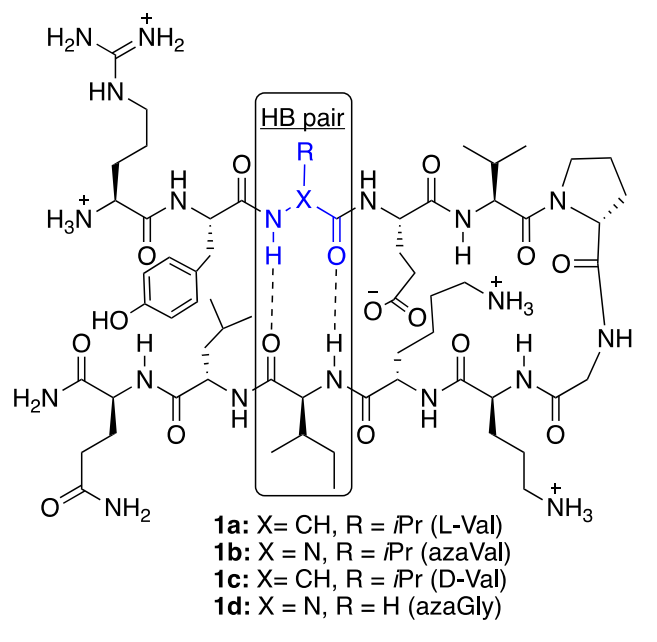

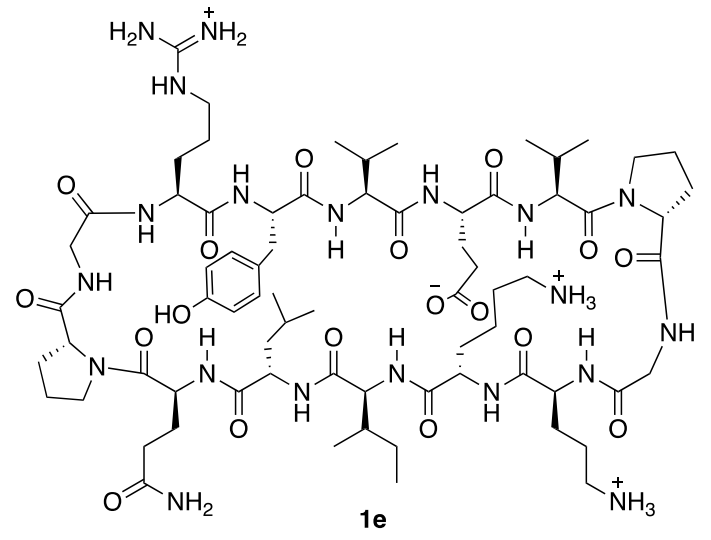

1d: $X=N, R=H$ (azaGly)<smiles>CCC(C)C(NC(=O)C(CCCC[NH3+])NC(=O)C(CCC[NH3+])NC(=O)CNC(=O)C1CCCN1C(=O)C(NC(=O)[C@H](CCC(=O)[O-])NC(=O)C(NC(=O)[C@H](Cc1ccc(O)cc1)NC(=O)[C@H](N)CCCNC(N)=[NH2+])C(C)C)C(C)C)C(=O)N[C@@H](CC(C)C)C(=O)N[C@@H](CCC(N)=O)C(N)=O</smiles>

Figure 2. $\beta$-hairpin model peptide 1a [8], derivatives $\mathbf{1} \mathbf{b}-\mathbf{d}$, and controls $\mathbf{1 e - f}$ [8] under study. 


\section{Results and Discussion}

\subsection{Synthesis}

Solid-phase peptide synthesis was performed on Rink amide resin, using standard Fmoc procedures for all $\mathrm{L}^{-}$and $\mathrm{D}$-amino acid coupling and deprotection cycles [16]. Incorporation of $\mathrm{azaVal}^{3}$ for the synthesis of $\mathbf{1} \mathbf{b}$ was accomplished via activation of $N^{\prime}$-isopropyl-fluorenylmethyl carbazate [17] using bis-(trichloromethyl)carbonate (BTC) as the activating agent (Scheme 1) and as a safer alternative to phosgene. Although submonomer azapeptide synthesis protocols [18] were considered for the installation of aza-valine to circumvent the solution-phase synthesis and activation of hydrazine building blocks, $N$-alkylation of resin-bound semicarbazone intermediates with sterically hindered secondary alkyl halides has typically resulted in lower conversions [19]. In our hands, incorporation of aza-valine via $N^{\prime}$-alkyl fluoren-9-ylmethyl carbazate activation with triphosgene afforded azapeptide 6 as the major product in 77\% crude purity after a single overnight coupling reaction. In contrast, in accordance with previous literature, coupling to the aza-amino acid to give 9 was challenging due to the decreased nucleophilicity of semicarbazides [8] and steric hindrance from the branched aza-valine side chain. In the past, coupling to aza-valine and other aza-amino acids with branched side chains has been accomplished using $N, N^{\prime}$-dicyclohexylcarbodiimide (DCC) [15], diisoproylcarbodiimide (DIC) [19,20], and BTC [21]. Here, the coupling of Fmoc-Tyr $\left({ }^{\mathrm{t}} \mathrm{Bu}\right)$ to resin-bound azaV-EVpGOKILQ using BTC and 2,4,6-collidine in tetrahydrofuran (THF) provided 9 in only $33 \%$ conversion by liquid chromatography-mass spectrometry (LC-MS) analysis, with 21\% uncoupled semicarbazide and $28 \%$ isocyanate or hydantoin byproduct [22] (Table 1, entry 1). In the context of $\beta$-hairpin synthesis, the already difficult coupling to aza-Val may be rendered even more challenging by folding or aggregation on-resin [23]. Attempts employing a $\mathrm{LiCl}$ salt additive to the BTC coupling solution to disrupt possible on-resin aggregation [24] were less successful than efforts to optimize the coupling reagent (Table 1, entries 2-5).

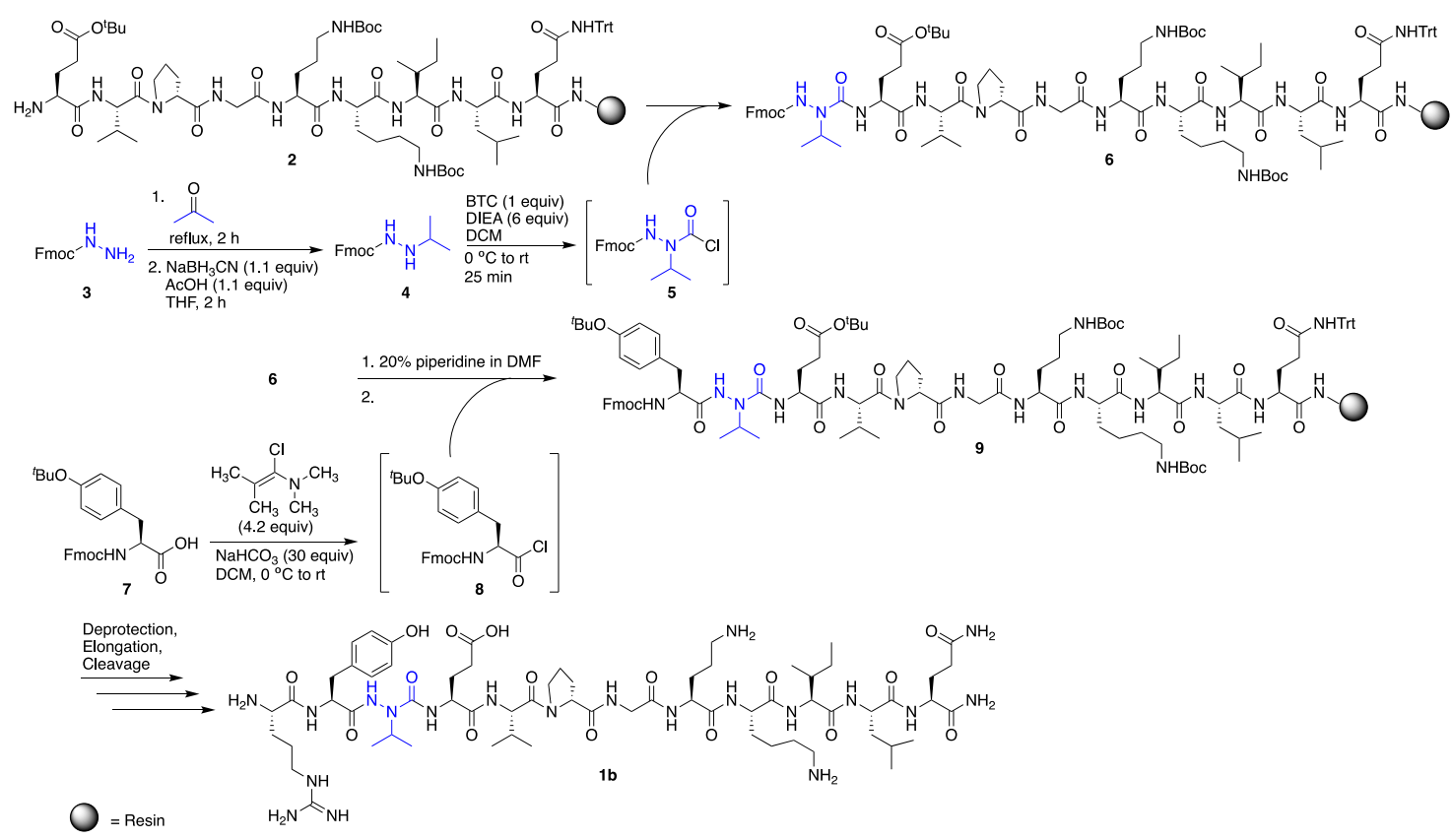

Scheme 1. Synthesis of azapeptide $\mathbf{1 b}$.

Recent successes using benzotriazol-1-yloxytris(pyrrolidinophosphonium-hexafluorophosphate (PyBOP)/N,N-diisopropylethylamine (DIEA) [25] and (1-cyano-2-ethoxy-2-oxoethylidenaminooxy) dimethylaminomorpholino-carbenium hexafluorophosphate (COMU)/DIEA [26,27] in difficult couplings to aza-amino acids led us to try these activating agents; however, 9 was obtained in low conversions in both 
cases (6-13\%, Table 1, entries 2 and 3). We next investigated $N, N, N^{\prime}, N^{\prime}$-tetramethylchloroformamidinium hexafluorophosphate (TCFH)/N-methylimidazole (NMI) (Table 1, entry 4), which was recently developed [28] to couple sterically hindered carboxylic acids with non-nucleophilic aniline derivatives and sterically hindered amino acids, including valine. Gratifyingly, these conditions provided 9 in high conversion ( $89 \%$ ) with little byproduct formation and no detectable starting material (Table 1, entry 4 ), although appearance of two peaks with identical masses by LC-MS suggested possible epimerization. Alternatively, the use of 1-chloro- $N, N, 2$-trimethyl-1-propenylamine (Ghosez's reagent) [29] (Table 1, entry 5) provided the desired elongated azapeptide 9 as a single peak by LC-MS analysis in $67 \%$ conversion, with no uncoupled semicarbazide detected. Using this procedure for coupling onto azaVal, azapeptide $\mathbf{1 b}$ was obtained in $53 \%$ crude purity, following deprotection, elongation, and cleavage from the resin. Purification of the crude azapeptide by reverse phase - high performance liquid chromatography (RP-HPLC) afforded $\mathbf{1 b}$ in $8 \%$ yield (see Supporting Information).

Table 1. Optimization of coupling to resin-bound aza-VEVpGOKILQ.

\begin{tabular}{|c|c|c|c|c|c|c|c|c|}
\hline Entry & $\begin{array}{l}\text { Coupling } \\
\text { Reagent }\end{array}$ & Equiv. & Base & Equiv. & Solvent & $\%$ Coupled & $\%$ Uncoupled & $\begin{array}{c}\text { \% Isocyanate/ } \\
\text { Hydantoin } \\
\text { Byproduct }[22]\end{array}$ \\
\hline 1 & BTC & 1 & 2,4,6-collidine & 10 & THF & 33 & 21 & 28 \\
\hline 2 & PyBOP & 3 & DIEA & 6 & DMF & 6 & 35 & 41 \\
\hline 3 & COMU & 5 & DIEA & 10 & DMF & 13 & 17 & 53 \\
\hline 4 & $\mathrm{TCFH}^{\mathrm{a}}$ & 3 & NMI & 9 & $\mathrm{CH}_{2} \mathrm{Cl}_{2}$ & $89^{a}$ & 0 & 10 \\
\hline 5 & Ghosez & 4.2 & $\mathrm{NaHCO}_{3}$ & 30 & $\mathrm{CH}_{2} \mathrm{Cl}_{2}$ & 67 & 0 & 22 \\
\hline
\end{tabular}

Activation of $\mathrm{N}$-Fmoc-hydrazine with phosgene equivalents was previously shown to lead to the formation of a cyclic oxadiazolone [30]. Although ring-opening of this heterocycle to afford the desired Fmoc-protected azaGly-terminated peptides may be possible [30], activation and coupling of aza-glycine using these conditions has been reported to be problematic in certain cases [31]. Here, aza-glycine installation was accomplished by activating fluoren-9-methyl carbazate with $N, N^{\prime}$-disuccinimidyl carbonate (DSC) as the activating agent instead of BTC, which afforded the desired azapeptide in higher yields [32]. Fmoc-Tyr $\left({ }^{t} \mathrm{Bu}\right)-\mathrm{OH}$ activation and coupling to the resin-bound aza-glycine-terminated peptide was accomplished using BTC/2,4,6-collidine in THF and required no further optimization.

\subsection{Conformational Analysis}

$\beta$-Hairpin folding was first assessed by measuring the extent of diastereotopic $\mathrm{Gly}^{7} \mathrm{H} \alpha$ splitting in the turn region for each analog and comparing it to the fully folded cyclic control (Equation (1)), as previously described [33]. Using this method, the relative stability of each $\beta$-hairpin analog can be quickly compared as the glycine signals lie in a distinct region of the spectra (Figure 3, Table 2).

$$
\text { Fraction folded }=\left(\Delta \delta_{\text {Gly Obs }}\right) /\left(\Delta \delta_{\text {Gly } 100}\right)
$$

Replacing valine ${ }^{3}$ for an aza-valine residue in analog $\mathbf{1 b}$ caused a significant decrease in $\beta$-hairpin stability, reflected by the much smaller $\mathrm{Gly}^{7} \delta \mathrm{H} \alpha-\delta \mathrm{H} \alpha^{\prime}$ value (Figure 3). Potential cross-strand hydrogen bonding and side chain - side chain interactions between azaVal ${ }^{3}$ and $\mathrm{Ile}^{10}$ appear to be insufficient to stabilize the extended conformation in aza-valine ${ }^{3}$, which likely adopts a twisted conformation $\left(\varphi=90^{\circ}\right)$ that disrupts $\beta$-hairpin formation. Because aza-amino acids may exhibit adaptive chirality at $\mathrm{N} \alpha$, the aza-valine residue could be achiral or exhibit either L or D-like chirality [34], which could in turn affect $\beta$-hairpin stability. We synthesized D-Val ${ }^{3}$ analog $1 \mathbf{c}$ as a control and found its $\mathrm{Gly}^{7} \delta \mathrm{H} \alpha-\delta \mathrm{H} \alpha^{\prime}$ value to be larger than that of aza- $\mathrm{Val}^{3}$ analog $\mathbf{1 b}$, yet smaller than the parent peptide 1a. While changing the stereochemistry of the valine ${ }^{3}$ residue from $\mathrm{L}$ to $\mathrm{D}$ decreased $\beta$-hairpin stability overall, this substitution was found to be less disruptive than the backbone $\mathrm{C} \alpha$ to $\mathrm{N} \alpha$ substitution 
in the aza-valine residue. As such, the destabilizing effect of the aza-valine residue cannot be solely attributed to the loss of a defined stereocenter.

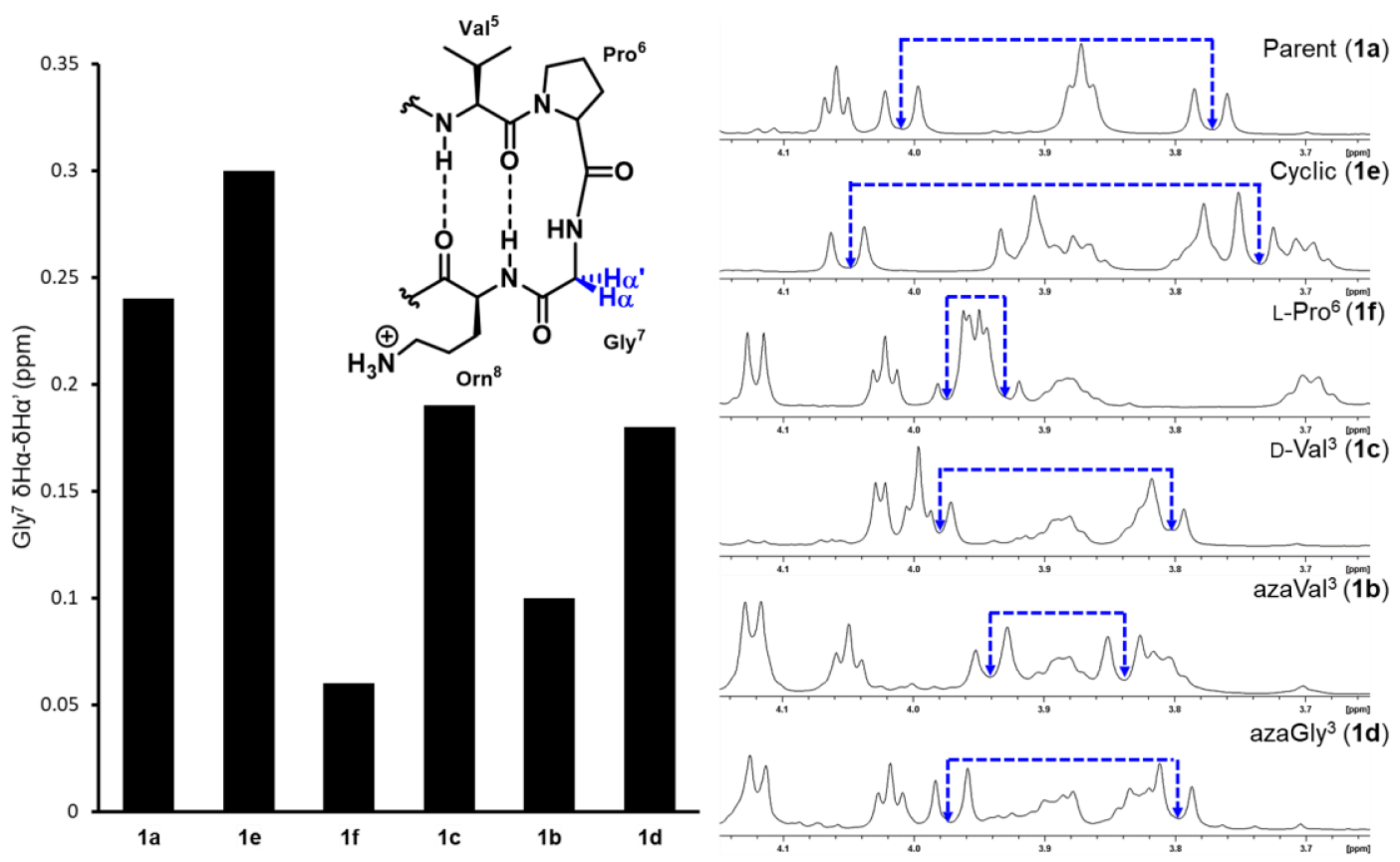

Figure 3. Diastereotopic splitting of $\mathrm{Gly}^{7} \mathrm{H} \alpha$ chemical shifts.

Given that the extended conformation in aza-glycine vs. aza-valine residues may be more favorable due to additional intramolecular hydrogen-bonding interactions (vide supra), the synthesis and conformational analysis of azaGly ${ }^{3}$ analog 1d was also pursued. Despite the absence of an isopropyl side chain, the aza-glycine substitution was found to be less detrimental to $\beta$-hairpin stability compared to the aza- $\mathrm{Val}^{3}$ analog $\mathbf{1 b}$; however, $\beta$-hairpin folding was still decreased relative to the parent peptide 1a. The disruptive effects of the azaGly ${ }^{3}$ substitution are similar those observed in the D-Val ${ }^{3}$ analog using $\mathrm{Gly}^{7}$ diastereotopic $\mathrm{H} \alpha$ splitting measurements (Figure 3) [35].

It should be noted that glycine splitting measurements have been found to overestimate $\beta$-hairpin folding in sequences that use D-Pro-Gly turn units [36]. Downfield chemical shifts in $\mathrm{CH} \alpha$ protons relative to unfolded peptide for residues away from the turn region, especially those situated at $\mathrm{HB}$ sites, can be used to quantify the degree of $\beta$-hairpin folding more reliably according to Equation (2), where $\delta_{0}$ and $\delta_{100}$ are the chemical shift values for the unfolded analog $\mathbf{1 f}$ and the cyclic control 1e, respectively.

$$
\text { Fraction folded }=\left(\delta_{\mathrm{Obs}}-\delta_{0}\right) /\left(\delta_{100}-\delta_{0}\right)
$$

Specifically, the downfield chemical shifts of $\mathrm{Val}^{3}, \mathrm{Ile}^{10}$, and $\mathrm{Orn}^{8}$ have been found to be more reliable and are typically used to measure folded fractions for this $\beta$-hairpin model peptide and its derivatives [14]. Here, because the $\mathrm{C} \alpha$ of $\mathrm{Val}^{3}$ is substituted by a nitrogen in our azapeptide analogs, we omitted this residue from our studies (Table 2). The $\mathrm{CH} \alpha$ chemical shift values for $\mathrm{Ile}^{10}$ are particularly informative because this residue sits in the middle of the lower strand and is positioned to form hydrogen bonds with the variable residue in the third position; Orn ${ }^{8}$ is situated closer to the turn region. Based on the chemical shift values for $\mathrm{Ile}^{10}$, aza-Val ${ }^{3}$ peptide $1 \mathrm{~b}$ is completely unfolded, in contrast to the partially folded structure predicted based on glycine ${ }^{7} \mathrm{H} \alpha$ splitting measurements (Figure 3, Table 2). Considering that diastereotopic splitting of Gly ${ }^{7} \mathrm{H} \alpha$ overestimate folding in $\beta$-hairpin model peptides that have D-Pro-Gly turn units, incorporation of azaVal ${ }^{3}$ is likely completely disrupting the $\beta$-hairpin fold. In contrast, the azaGly ${ }^{3}$ analog $1 \mathrm{~d}$ which lacks side chain functionality was $\sim 50 \%$ folded based on the $\mathrm{Ile}^{10}$ downfield $\mathrm{H} \alpha$ chemical shifts, and exhibited a greater percentage 
of folding relative to both the aza-valine (1a) and D-valine (1c) analogs. The additional potential for azaGly to intra- and/or inter-strand hydrogen-bond may stabilize the extended conformer. The \% folding values calculated from Orn $^{8}$ chemical shifts reinforced the conclusion that the aza-Valine analog $1 \mathrm{~b}$ was the least folded of all analogs, yet suggested similar degrees of folding for the $\mathrm{D}-\mathrm{Val}$ (1c) and the azaGly (1d) analogs.

Table 2. \% folding based on glycine ${ }^{7}$ splitting and $\mathrm{H} \alpha$ chemical shifts for $\mathrm{Orn}^{8}$ and $\mathrm{Ile}^{10}$.

\begin{tabular}{ccccc}
\hline \multirow{2}{*}{ Peptide } & \multicolumn{4}{c}{$\%$ Folding } \\
\cline { 2 - 5 } & $\mathbf{G l y}^{\mathbf{7}} \boldsymbol{\delta} \mathbf{H} \boldsymbol{\alpha}-\boldsymbol{\delta} \mathbf{H} \boldsymbol{\alpha}^{\mathbf{\prime}}$ & Orn $^{\mathbf{8}}$ & $\mathbf{I l e}^{\mathbf{1 0}}$ & Average from Orn $^{\mathbf{8}} / \mathbf{I l e}^{\mathbf{1 0}}$ \\
\hline $\mathbf{1 a}$ & 75 & 72 & 64 & 68 \\
$\mathbf{1 b}$ & 17 & 36 & 0 & 18 \\
$\mathbf{1 c}$ & 54 & 56 & 15 & 35.5 \\
$\mathbf{1 d}$ & 50 & 50 & 49 & 49.5 \\
\hline
\end{tabular}

\section{Materials and Methods}

\subsection{General}

Polystyrene Rink Amide resin (0.78 mmol/g) and Fmoc-glycine-2-chlorotrityl resin (200-400 mesh, $0.493 \mathrm{mmol} / \mathrm{g}$ ) were purchased from Protein Technology Inc ${ }^{\mathrm{TM}}$ and Chem-Impex Int'l, Inc, respectively, and the manufacturer's reported loading of the resin was used in the calculation of the yields of the final products. Solid phase peptide synthesis was performed using an automated Biotage Syro Wave ${ }^{\mathrm{TM}}$ peptide synthesizer in $10 \mathrm{~mL}$ parallel reactors with polytetrafluoroethylene (PTFE) frits. Incorporation of aza-amino acids and further elongations were performed manually in disposable filter columns with $20 \mu \mathrm{M}$ polyethylene (PE) frit filters and caps purchased from Applied Separations (cat \# 2413 and 2416 for $3 \mathrm{~mL}$ and $6 \mathrm{~mL}$ filter columns, respectively) with gentle agitation on a Thermo Fisher vortex mixer equipped with a microplate tray. Solution draining and washing of the resin was accomplished by connecting the filter columns to a water aspirator vacuum via a waste trap. Analytical LC-MS analyses were performed using an Agilent Technologies 1260 Infinity II series LC-MS Single Quad instrument with ESI ion-source and positive mode ionization, equipped with a $5 \mu \mathrm{M}, 150 \times 4.6 \mathrm{~mm} \mathrm{C} 18 \mathrm{Vydac}$ column purchased from Mac-Mod Analytical, Inc (cat \# 218TP5415). A flow rate of $0.5 \mathrm{~mL} / \mathrm{min}$ and $5-95 \%, 20-80 \%$, or $12-60 \%$ gradients of $\mathrm{CH}_{3} \mathrm{CN}[0.1 \%$ trifluoroacetic acid (TFA)] in water $(0.1 \%$ TFA) over $12 \mathrm{~min}$ (total run time $=22 \mathrm{~min}$ ) were used for all LC-MS analyses. Peptides were purified on a preparative HPLC (Agilent 218 purification system) using a preparative column (10-20 $\mu \mathrm{M}, 250 \mathrm{~mm} \times$ $22 \mathrm{~mm}, \mathrm{C} 18 \mathrm{Vydac}$ column, cat \# 218TP101522) at a flow rate of $10 \mathrm{~mL} / \mathrm{min}$ with gradients of $\mathrm{CH}_{3} \mathrm{CN}$ $[0.1 \%$ trifluoroacetic acid (TFA)] in water $(0.1 \%$ TFA) over $30 \mathrm{~min}$ (total run time $=60 \mathrm{~min})$.

\subsection{Reagents}

Amino acids, $N, N^{\prime}$-diisopropylethylamine (DIEA), $N, N^{\prime}$-Disuccinimidyl carbonate (DSC), Fmoc chloride, (1-cyano-2-ethoxy-2-oxoethylidenaminooxy)dimethylamino-morpholino-carbenium hexafluorophosphate (COMU), chloro- $N, N, N^{\prime}, N^{\prime}$-tetramethylformamidinium hexafluorophospate (TCFH) and triphosgene (BTC) were purchased from Chem Impex Int'l, Inc. Reagents such as piperidine, lithium chloride, sodium cyanoborohydride $\left(\mathrm{NaBH}_{3} \mathrm{CN}\right)$, triisopropylsilane (TIPS), sodium acetate- $\mathrm{d}_{3}$, acetic acid- $\mathrm{d}_{4}$, and $\mathrm{D}_{2} \mathrm{O}$ were purchased from Sigma Aldrich. Reagents such as hydrazine monohydrate and 2,4,6-collidine were purchased from Alfa Aesar. Trifluoroacetic acid, glacial acetic acid, sodium bicarbonate, and solvents were purchased from Fisher. Reagents including HBTU and PyBOP were purchased from Oakwood Chemical. 1-Methylimidazole (NMI) and 1-chloro-N,N,2-trimethylpropenylamine (Ghosez's Reagent) were purchased from Acros Organics. 
3.3. 9-Fluorenylmethoxycarbonyl (Fmoc)-Based Solid Phase Peptide Synthesis (SPPS): Fmoc Deprotection and HBTU Couplings

Peptide syntheses were performed under standard manual conditions on an automated shaker or using a Biotage Syro Wave ${ }^{\mathrm{TM}}$ peptide synthesizer using Polystyrene Rink Amide resin $(0.78 \mathrm{mmol} / \mathrm{g})$. Couplings of amino acids (3 equiv) were performed in DMF using HBTU (3 equiv) as coupling reagent and DIEA (6 equiv) as base. Fmoc deprotections were performed initially by treating the resin with $20 \%$ piperidine in DMF $(v / v)$ for $5 \mathrm{~min}$, followed by treatment with a fresh solution of $20 \%$ piperidine in DMF (v/v) for $15 \mathrm{~min}$. Resin was washed after each coupling with DMF $(3 \times 1 \mathrm{~mL})$ and deprotection reaction with $\mathrm{DMF}, \mathrm{MeOH}$, and $\mathrm{CH}_{2} \mathrm{Cl}_{2}(2 \times 1 \mathrm{~mL})$. Prior to cleavage from the resin or storage, resin was washed with $\mathrm{CH}_{2} \mathrm{Cl}_{2}(3 \times 1 \mathrm{~mL})$.

\subsection{Test Cleavages of Resin-Bound Peptides}

A small amount of resin (1-5 mg) was washed with $\mathrm{CH}_{2} \mathrm{Cl}_{2}$ to remove traces of $\mathrm{DMF}$, drained, and treated with a freshly made solution of TFA/ $\mathrm{H}_{2} \mathrm{O} / \mathrm{TIPS}(90: 5: 5, v / v / v, 0.5 \mathrm{~mL})$ for $2 \mathrm{~h}$ at room temperature. The cleavage solution was collected by filtering the resin through a disposable, PE fritted cartridge. The filtrate was evaporated to dryness and the crude peptide was precipitated twice with cold ether $(4 \mathrm{~mL})$ followed by decanting. The pellet (crude peptide sample) was dissolved in 1:1 $\mathrm{MeCN} / \mathrm{H}_{2} \mathrm{O} v / v(1 \mathrm{mg} / \mathrm{mL})$ and subjected to LC-MS analysis.

\subsection{N'-Isopropyl-fluoren-9-ylmethyl Carbazate (4)}

Synthesized according to literature procedures [12,16]. Briefly, a solution of Fmoc-Cl (2.00 g, $7.73 \mathrm{mmol}$ ) in $120 \mathrm{~mL}$ of $\mathrm{CH}_{3} \mathrm{CN}$ was added dropwise over $2 \mathrm{~h}$ at $0{ }^{\circ} \mathrm{C}$ to a solution of excess hydrazine hydrate (3.8 mL, $78.0 \mathrm{mmol}, 10$ equiv) in $26 \mathrm{~mL}$ of $\mathrm{CH}_{3} \mathrm{CN} / \mathrm{H}_{2} \mathrm{O}(1: 1, v / v)$. The solution was warmed to room temperature and left stirring for $12 \mathrm{~h}$, prior to being concentrated in vacuo and filtered. The resulting solid was washed with water, followed by hexanes, to give $1.92 \mathrm{~g}$ of white solid in $98 \%$ yield. The resulting 9H-fluoren-9-ylmethyl hydrazinecarboxylate 3 (1.92 g, $7.55 \mathrm{mmol})$ was suspended in acetone $(50 \mathrm{~mL})$ and heated at reflux for $2 \mathrm{~h}$. Acetone was evaporated in vacuo and the hydrazone intermediate was dissolved in THF $(50 \mathrm{~mL})$, treated with acetic acid $(0.48 \mathrm{~mL}, 8.39 \mathrm{mmol}, 1.1$ equiv) and $\mathrm{NaBH}_{3} \mathrm{CN}$ (521 mg, $8.31 \mathrm{mmol}, 1.1$ equiv), and stirred for $2 \mathrm{~h}$. The volatiles were removed and the crude was dissolved in EtOAc $(100 \mathrm{~mL})$, washed with $1 \mathrm{M}$ aqueous $\mathrm{KHSO}_{4}(4 \times 50 \mathrm{~mL})$ and brine $(2 \times 50 \mathrm{~mL})$, dried over $\mathrm{Na}_{2} \mathrm{SO}_{4}$, and concentrated to give a white solid. The obtained product was dissolved in EtOH and heated for $1 \mathrm{~h}$, followed by evaporation of EtOH to yield $N^{\prime}$-isopropyl-fluoren-9-ylmethyl carbazate 4 as a white solid (1.32 g, 59\% yield) after column chromatography using a 20-100\% gradient of EtOAc in hexanes. NMR $\left(\mathrm{CDCl}_{3}\right)$ spectra matched literature values [12].

\subsection{Incorporation of Aza-Valine on the Solid Phase}

$N^{\prime}$-isopropyl-fluoren-9-ylmethyl carbazate 4 (138 mg, $0.466 \mathrm{mmol}, 3$ equiv) was dissolved in dry $\mathrm{CH}_{2} \mathrm{Cl}_{2}(1 \mathrm{~mL})$ and cooled to $0{ }^{\circ} \mathrm{C}$. A solution of bis(trichloromethyl)carbonate (BTC, $46.4 \mathrm{mg}$, $0.156 \mathrm{mmol}, 1$ equiv) dissolved in dry $\mathrm{CH}_{2} \mathrm{Cl}_{2}(1 \mathrm{~mL})$ and cooled to $0^{\circ} \mathrm{C}$ was added dropwise to the $N^{\prime}$-isopropyl-fluoren-9-ylmethyl carbazate suspension. The reaction mixture was left stirring at $0{ }^{\circ} \mathrm{C}$ for $5 \mathrm{~min}$, allowed to warm to room temperature, and stirred for another $25 \mathrm{~min}$. DIEA (0.163 $\mathrm{mL}$, $0.930 \mathrm{mmol}, 6.0$ equiv) was added to the solution and the solution was stirred for 5 min prior to being transferred to a SPPS cartridge containing resin-bound peptide 2 (200 $\mathrm{mg}, 0.156 \mathrm{mmol})$ swollen in $\mathrm{CH}_{2} \mathrm{Cl}_{2}$. The SPPS cartridge was left shaking for $12 \mathrm{~h}$, after which the solution was drained, and the resin was washed with $\mathrm{CH}_{2} \mathrm{Cl}_{2}(3 \times 2 \mathrm{~mL})$. 


\subsection{Coupling to AzaV-EVpGOKILQ}

\subsubsection{BTC Coupling}

Fmoc-Tyr $\left({ }^{t} \mathrm{Bu}\right)-\mathrm{OH}(53.8 \mathrm{mg}, 0.117 \mathrm{mmol}, 3.0$ equiv) was dissolved in dry THF $(0.3 \mathrm{~mL})$, cooled to $0{ }^{\circ} \mathrm{C}$, and treated dropwise with a cold solution of BTC $(11.5 \mathrm{mg}, 0.039 \mathrm{mmol}, 1.0$ equiv) in dry THF $(0.3 \mathrm{~mL})$. The reaction mixture was left stirring at $0{ }^{\circ} \mathrm{C}$ for $15 \mathrm{~min}$, before adding 2,4,6-collidine ( $0.052 \mathrm{~mL}, 0.39 \mathrm{mmol}, 10.0$ equiv). The solution was stirred at $0{ }^{\circ} \mathrm{C}$ for $2 \mathrm{~min}$, allowed to warm to room temperature, and stirred another $5 \mathrm{~min}$. The activated amino acid was then transferred to a SPPS cartridge containing the resin-bound azapeptide $(50 \mathrm{mg}, 0.039 \mathrm{mmol})$, previously swollen in dry THF. The resin was left shaking at room temperature overnight, then washed with DMF $(2 \times 0.5 \mathrm{~mL}), \mathrm{MeOH}$ $(2 \times 0.5 \mathrm{~mL})$, and THF $(2 \times 0.5 \mathrm{~mL})$.

\subsubsection{PyBOP Coupling}

Fmoc-Tyr $\left({ }^{t} \mathrm{Bu}\right)-\mathrm{OH}(53.8 \mathrm{mg}, 0.117 \mathrm{mmol}, 3.0$ equiv) and PyBOP $(60.9 \mathrm{mg}, 0.117 \mathrm{mmol}, 3.0$ equiv) were each dissolved in DMF $(0.3 \mathrm{~mL})$ and cooled to $0{ }^{\circ} \mathrm{C}$ separately. The PyBOP solution was then added dropwise to the solution of $\mathrm{Fmoc}-\mathrm{Tyr}\left({ }^{t} \mathrm{Bu}\right)-\mathrm{OH}$ and the reaction mixture was stirred at $0{ }^{\circ} \mathrm{C}$ for $5 \mathrm{~min}$. DIEA $(0.0408 \mathrm{~mL}, 0.234 \mathrm{mmol}, 6.0$ equiv) was added to the solution and the reaction was allowed to warm to room temperature before being transferred to a SPPS cartridge containing the resin-bound azapeptide ( $50 \mathrm{mg}, 0.039 \mathrm{mmol})$, previously swollen in DMF. The resin was shaken at room temperature overnight, then washed with DMF $(2 \times 0.5 \mathrm{~mL}), \mathrm{MeOH}(2 \times 0.5 \mathrm{~mL})$, and $\mathrm{CH}_{2} \mathrm{Cl}_{2}$ $(2 \times 0.5 \mathrm{~mL})$.

\subsubsection{COMU Coupling}

Fmoc-Tyr $\left({ }^{t} \mathrm{Bu}\right)-\mathrm{OH}(89.6 \mathrm{mg}, 0.195 \mathrm{mmol}, 5.0$ equiv) and COMU ( $83.5 \mathrm{mg}, 0.195 \mathrm{mmol}, 5.0$ equiv) were each dissolved in $0.3 \mathrm{~mL}$ of DMF and cooled to $0{ }^{\circ} \mathrm{C}$ separately. The COMU solution was added dropwise to the solution of Fmoc-Tyr $\left({ }^{t} \mathrm{Bu}\right)-\mathrm{OH}$ and the reaction mixture was stirred at $0{ }^{\circ} \mathrm{C}$ for $5 \mathrm{~min}$. DIEA $(0.0504 \mathrm{~mL}, 0.39 \mathrm{mmol}, 10.0$ equiv) was added and the reaction was warmed to room temperature before being transferred to a SPPS cartridge containing the resin-bound azapeptide ( $50 \mathrm{mg}, 0.039 \mathrm{mmol})$, previously swollen in DMF. The resin was shaken at room temperature overnight, then washed with $\mathrm{DMF}(2 \times 0.5 \mathrm{~mL}), \mathrm{MeOH}(2 \times 0.5 \mathrm{~mL})$, and $\mathrm{CH}_{2} \mathrm{Cl}_{2}(2 \times 0.5 \mathrm{~mL})$.

\subsubsection{NMI/TCFH Coupling}

Fmoc-Tyr $\left({ }^{t} \mathrm{Bu}\right)-\mathrm{OH}\left(53.8 \mathrm{mg}, 0.117 \mathrm{mmol}, 3.0\right.$ equiv) was dissolved in dry $\mathrm{CH}_{2} \mathrm{Cl}_{2}(0.3 \mathrm{~mL})$, to which $\mathrm{N}$-methyl imidazole $\left(0.028 \mathrm{~mL}, 0.351 \mathrm{mmol}, 9\right.$ equiv) was added before cooling the solution to $0{ }^{\circ} \mathrm{C}$. A solution of TCFH ( $32.8 \mathrm{mg}, 0.117 \mathrm{mmol}, 3$ equiv) in dry $\mathrm{CH}_{2} \mathrm{Cl}_{2}(0.3 \mathrm{~mL})$, cooled to $0{ }^{\circ} \mathrm{C}$, was added to the Fmoc-Tyr $\left({ }^{t} \mathrm{Bu}\right)-\mathrm{OH}$ and NMI solution in a single portion and the reaction was immediately transferred to a SPPS cartridge containing the resin-bound azapeptide $(50 \mathrm{mg}, 0.039 \mathrm{mmol})$, previously swollen in dry $\mathrm{CH}_{2} \mathrm{Cl}_{2}$. The resin was shaken at room temperature overnight, then washed with DMF $(2 \times 0.5 \mathrm{~mL}), \mathrm{MeOH}(2 \times 0.5 \mathrm{~mL})$, and $\mathrm{CH}_{2} \mathrm{Cl}_{2}(2 \times 0.5 \mathrm{~mL})$.

\subsubsection{Ghosez Coupling}

$\mathrm{NaHCO}_{3}$ (98.3 mg, $1.17 \mathrm{mmol}, 30$ equiv) was added to the resin-bound azapeptide (50 $\mathrm{mg}$, $0.039 \mathrm{mmol})$ pre-swelled in dry $\mathrm{CH}_{2} \mathrm{Cl}_{2}(0.2 \mathrm{~mL})$ and shaken for $15 \mathrm{~min}$. During that time, Fmoc-Tyr $\left({ }^{t} \mathrm{Bu}\right)-\mathrm{OH}\left(53.8 \mathrm{mg}, 0.117 \mathrm{mmol}, 3.0\right.$ equiv) was dissolved in dry $\mathrm{CH}_{2} \mathrm{Cl}_{2}(0.4 \mathrm{~mL})$ and cooled to $0{ }^{\circ} \mathrm{C}$. Ghosez's reagent $(0.0217 \mathrm{~mL}, 0.164 \mathrm{mmol}, 4.2$ equiv) was added dropwise to the cooled solution of Fmoc- $\operatorname{Tyr}\left({ }^{t} \mathrm{Bu}\right)-\mathrm{OH}$ and stirred for $5 \mathrm{~min}$. The reaction was allowed to warm to room temperature for $5 \mathrm{~min}$, prior to being transferred to the SPPS cartridge containing $\mathrm{NaHCO}_{3}$ in $\mathrm{CH}_{2} \mathrm{Cl}_{2}$. The resin was shaken at room temperature overnight. The resin was washed with DMF $(2 \times 0.5 \mathrm{~mL})$, $\mathrm{MeOH}(2 \times 0.5 \mathrm{~mL})$, and $\mathrm{CH}_{2} \mathrm{Cl}_{2}(2 \times 0.5 \mathrm{~mL})$. 


\subsection{Incorporation of Aza-Glycine on the Solid Phase}

$N, N^{\prime}$-Disuccinimidyl carbonate (DSC) $(120 \mathrm{mg}, 0.466 \mathrm{mmol}, 3.0$ equiv) was added to a solution of 9H-fluoren-9-ylmethyl hydrazinecarboxylate 3 (123 mg, $0.484 \mathrm{mmol}, 3.1$ equiv) in DMF and stirred for $5 \mathrm{~min}$. The solution was then transferred to resin-bound peptide 2 ( $200 \mathrm{mg}, 0.156 \mathrm{mmol})$ swollen in DMF and left shaking for $12 \mathrm{~h}$. The solution was drained and the resin was washed with DMF $(3 \times 2 \mathrm{~mL})$.

\subsection{Coupling to azaG-EVpGOKILQ}

Fmoc-Tyr $\left({ }^{t} \mathrm{Bu}\right)-\mathrm{OH}(22.2 \mathrm{mg}, 0.0484 \mathrm{mmol}, 3.1$ equiv $)$ was dissolved in dry THF $(0.3 \mathrm{~mL})$, cooled to $0{ }^{\circ} \mathrm{C}$, and treated dropwise with a cold solution of BTC (4.63 $\mathrm{mg}, 0.0156 \mathrm{mmol}, 1.0$ equiv) in dry THF $(0.2 \mathrm{~mL})$. The reaction mixture was left stirring at $0^{\circ} \mathrm{C}$ for $15 \mathrm{~min}$ before adding 2,4,6-collidine ( $0.0206 \mathrm{~mL}, 0.156 \mathrm{mmol}, 10.0$ equiv). The solution was stirred at $0{ }^{\circ} \mathrm{C}$ for $5 \mathrm{~min}$. The reaction was allowed to warm to room temperature prior to transferring the activated amino acid to a SPPS cartridge containing the resin-bound azapeptide $(20 \mathrm{mg}, 0.0156 \mathrm{mmol})$ previously swollen with dry THF. The reaction was left shaking at room temperature overnight, then washed with DMF $(2 \times 0.5 \mathrm{~mL})$, $\mathrm{MeOH}(2 \times 0.5 \mathrm{~mL})$, and THF $(2 \times 0.5 \mathrm{~mL})$.

\subsection{Synthesis of Cyclic Peptide 1e}

The linear precursor $\mathrm{H}_{2} \mathrm{~N}-\mathrm{Arg}(\mathrm{Pbf})-\mathrm{Tyr}\left({ }^{t} \mathrm{Bu}\right)-\mathrm{Val}-\mathrm{Glu}\left(\mathrm{O}^{t} \mathrm{Bu}\right)-\mathrm{Val}-$ pro-Gly-Orn(Boc)-Lys(Boc)-IleLeu-Gln(Trt)-pro-Gly-OH was synthesized on Fmoc-glycine-2-chlorotrityl resin (200-400 mesh, $0.493 \mathrm{mmol} / \mathrm{g}$ loading) according to standard SPPS protocols described above. Liberation of the side chain protected peptide from solid support was conducted using a freshly prepared solution of hexafluoroisopropanol in $\mathrm{CH}_{2} \mathrm{Cl}_{2}(20 \% \mathrm{v} / \mathrm{v})$, the procedure was repeated, solutions were combined, and volatiles were removed in vacuo. The protected linear peptide was dissolved in DMF (15 mL) and a solution of HBTU (41.2 mg, 0.109 mmol, 6 equiv) and $\mathrm{HOBt}^{\bullet} \mathrm{H}_{2} \mathrm{O}(16.6 \mathrm{mg}, 0.109 \mathrm{mmol}, 6$ equiv) in DMF (1 mL) was added dropwise, followed by an addition of DIEA $(0.0494 \mathrm{~mL}, 0.283 \mathrm{mmol}$, 15 equiv) in DMF $(1 \mathrm{~mL})$. The reaction was allowed to proceed overnight under $\mathrm{N}_{2}$ atmosphere. DMF was removed in vacuo and the cyclic side chain protected peptide was carried forward to global deprotection. A fresh 90:5:5 (v/v/v) solution of TFA: $\mathrm{H}_{2} \mathrm{O}$ : TIPS was prepared and $10 \mathrm{~mL}$ were added to the dried peptide. The reaction was stirred for $2 \mathrm{~h}$ at room temperature, followed by the removal of all volatiles in vacuo. Cold ether precipitation was performed followed by dissolution of the cyclic peptide in $20 \% \mathrm{MeCN}$ in water $(3 \mathrm{~mL})$. The crude peptide sample was purified by RP-HPLC according to protocols described in General Methods.

\subsection{Full Cleavage and Purification of (Aza)Peptides}

The resin-bound (aza)peptide was washed with $\mathrm{CH}_{2} \mathrm{Cl}_{2}$ to remove traces of DMF, drained, transferred into a $20 \mathrm{~mL}$ scintillation glass vial, and treated a freshly made solution of TFA/ $\mathrm{H}_{2} \mathrm{O} / \mathrm{TIPS}$ (90:5:5, v/v/v, $5 \mathrm{~mL})$. The vial was capped and agitated for $2 \mathrm{~h}$ at room temperature on an orbital shaker. The cleavage mixture was filtered through a disposable, PP fritted cartridge into a $50 \mathrm{~mL}$ falcon tube containing cold ether $(\sim 20 \mathrm{~mL})$. The ether was decanted following centrifugation at $8000 \mathrm{rpm}$ for $2 \mathrm{~min}$. The peptide pellet was suspended in 1:9 MeCN/ $\mathrm{H}_{2} \mathrm{O} v / v(5 \mathrm{~mL})$. The sample was frozen and lyophilized. The crude (aza)peptpide was redissolved in a $\mathrm{MeCN} / \mathrm{H}_{2} \mathrm{O}$ solvent mixture and purified using reverse-phase HPLC. See Supporting Information for characterization data.

\subsection{NMR Spectroscopy}

Lyophilized (aza)peptides were diluted to concentrations of 3-4 $\mathrm{mM}$ in $\mathrm{D}_{2} \mathrm{O}$ buffered with $50 \mathrm{mM}$ NaOAc-d3 buffer at pH 4.2 (uncorrected), pH adjusted with AcOH-d3 [36]. All NMR spectra were collected at the Molecular Education, Technology, and Research Innovation Center (METRIC) at NC State University on a Bruker NEO $700 \mathrm{MHz}$ instrument with a TCI cryoprobe at $5{ }^{\circ} \mathrm{C}$. $1 \mathrm{D}$ spectra were collected with $32 \mathrm{~K}$ data points and at least 32 scans and water suppression with a pre-saturation 
pulse or with a 1D-1H NOESY. 2D-experiments were collected on the same instrumentation, using the standard Bruker ROESY, COSY, and TOCSY pulse sequences with presaturation. All 2D experiments were done with eight scans, 2048 points in the first dimension, and 256 or 512 in the indirect dimension. TOCSY spectra were collected with $80 \mathrm{~ms}$ spin-lock and ROESY spectra were collected with a mixing time of $200 \mathrm{~ms}$. Spectral analysis was performed with TopSpin 4.0 .5 software.

\section{Conclusions}

Aza-amino acids have previously been shown to stabilize $\beta$-turn secondary structures and impart hyperstability to self-assembling collagen peptide mimics. Here, we expand the folding rules for aza-amino acids beyond turns and polyproline type II helices and characterize their effect on $\beta$-hairpin stability when incorporated into the $\beta$-strand region. Using NMR spectroscopy, we demonstrate that a valine to aza-valine substitution significantly disrupts $\beta$-hairpin folding, based on both glycine splitting measurements and $\mathrm{CH} \alpha$ proton shifts at the $\mathrm{Orn}^{8}$ and $\mathrm{Il}^{10}{ }^{10}$ residues relative to cyclic and unfolded controls. Aza-glycine incorporation at the same position was found to retain some folding, despite loss of side chain chemistry, which may be due to additional hydrogen bonding. Overall, our findings support earlier computational hypothesis that aza-amino acids are not well tolerated within $\beta$-sheet secondary structures.

Supplementary Materials: The following are available online: peptide and aza(peptide) characterization data; LC-MS chromatograms; tabulated ${ }^{1} \mathrm{H}$ NMR data for all peptide and aza(peptide) analogs.

Author Contributions: Conceptualization, C.P. and M.A.M.; Methodology and Analysis, M.A.M., E.L.W., P.C.G.; Writing-Original Draft Preparation, C.P.; Writing-Review and Editing, C.P., M.A.M., E.L.W., P.C.G.; Supervision, C.P.; Project Administration, C.P.

Funding: This research received no external funding.

Acknowledgments: The authors thank Peter Thompson for assistance with NMR spectroscopy and North Carolina State University for startup support. All NMR measurements were made in the Molecular Education, Technology, and Research Innovation Center (METRIC) at North Carolina State University.

Conflicts of Interest: The authors declare no conflict of interest.

\section{References and Notes}

1. Cheng, P.N.; Pham, J.D.; Nowick, J.S. The Supramolecular Chemistry of beta-Sheets. J. Am. Chem. Soc. 2013, 135, 5477-5492. [CrossRef] [PubMed]

2. Watkins, A.M.; Arora, P.S. Anatomy of beta-Strands at Protein-Protein Interfaces. ACS Chem. Biol. 2014, 9 , 1747-1754. [CrossRef]

3. Hughes, R.M.; Waters, M.L. Model systems for beta-hairpins and beta-sheets. Curr. Opin. Struct. Biol. 2006, 16, 514-524. [CrossRef]

4. Loughlin, W.A.; Tyndall, J.D.A.; Glenn, M.P.; Fairlie, D.P. Beta-strand mimetics. Chem. Rev. 2004, 104, 6085-6117. [CrossRef]

5. Doig, A.J. A three stranded beta-sheet peptide in aqueous solution containing N-methyl amino acids to prevent aggregation. Chem. Commun. 1997, 22, 2153-2154. [CrossRef]

6. Nowick, J.S.; Chung, D.M.; Maitra, K.; Maitra, S.; Stigers, K.D.; Sun, Y. An unnatural amino acid that mimics a tripeptide beta-strand and forms beta-sheet like hydrogen-bonded dimers. J. Am. Chem. Soc. 2000, 122, 7654-7661. [CrossRef]

7. Sarnowski, M.P.; Kang, C.W.; Elbatrawi, Y.M.; Wojtas, L.; Del Valle, J.R. Peptide N-Amination Supports beta-Sheet Conformations. Angew. Chem. Int. Ed. 2017, 56, 2083-2086. [CrossRef]

8. Proulx, C.; Sabatino, D.; Hopewell, R.; Spiegel, J.; Ramos, Y.G.; Lubell, W.D. Azapeptides and their therapeutic potential. Future Med. Chem. 2011, 3, 1139-1164. [CrossRef]

9. Zhang, Y.T.; Malamakal, R.M.; Chenoweth, D.M. Aza-Glycine Induces Collagen Hyperstability. J. Am. Chem. Soc. 2015, 137, 12422-12425. [CrossRef] [PubMed]

10. Zhang, Y.T.; Herling, M.; Chenoweth, D.M. General Solution for Stabilizing Triple Helical Collagen. J. Am. Chem. Soc. 2016, 138, 9751-9754. [CrossRef] 
11. Thormann, M.; Hofmann, H.J. Conformational properties of azapeptides. J. Mol. Struct. THEOCHEM 1999, 469, 63-76. [CrossRef]

12. Reynolds, C.H.; Hormann, R.E. Theoretical study of the structure and rotational flexibility of diacylhydrazines: Implications for the structure of nonsteroidal ecdysone agonists and azapeptides. J. Am. Chem. Soc. 1996, 118, 9395-9401. [CrossRef]

13. Stanger, H.E.; Gellman, S.H. Rules for antiparallel beta-sheet design: D-Pro-Gly is superior to L-Asn-Gly for beta-hairpin nucleation. J. Am. Chem. Soc. 1998, 120, 4236-4237. [CrossRef]

14. Syud, F.A.; Espinosa, J.F.; Gellman, S.H. NMR-based quantification of beta-sheet populations in aqueous solution through use of reference peptides for the folded and unfolded states. J. Am. Chem. Soc. 1999, 121, 11577-11578. [CrossRef]

15. Hess, H.J.; Moreland, W.T.; Laubach, G.D. N- [2-Isopropyl-3-(L-Aspartyl-L-Arginyl)-Carbazoyl]-L-Tyrosyl-LValyl-L-Histidyl-L-Prolyl-L-Phenylalanine, an Isostere of Bovine Angiotensin Ii. J. Am. Chem. Soc. 1963, 85, 4040-4041. [CrossRef]

16. Meienhofer, J.; Waki, M.; Heimer, E.P.; Lambros, T.J.; Makofske, R.C.; Chang, C.D. Solid-Phase Synthesis without Repetitive Acidolysis. Int. J. Pept. Prot. Res. 1979, 13, 35-42. [CrossRef]

17. Boeglin, D.; Lubell, W.D. Aza-amino acid scanning of secondary structure suited for solid-phase peptide synthesis with Fmoc chemistry and aza-amino acids with heteroatomic side chains. J. Comb. Chem. 2005, 7, 864-878. [CrossRef]

18. Chingle, R.; Proulx, C.; Lubell, W.D. Azapeptide Synthesis Methods for Expanding Side-Chain Diversity for Biomedical Applications. Acc. Chem. Res. 2017, 50, 1541-1556. [CrossRef]

19. Sabatino, D.; Proulx, C.; Klocek, S.; Bourguet, C.B.; Boeglin, D.; Ong, H.; Lubell, W.D. Exploring Side-Chain Diversity by Submonomer Solid-Phase Aza-Peptide Synthesis. Org. Lett. 2009, 11, 3650-3653. [CrossRef]

20. Kurian, L.A.; Silva, T.A.; Sabatino, D. Submonomer synthesis of azapeptide ligands of the Insulin Receptor Tyrosine Kinase domain. Bioorg. Med. Chem. Lett. 2014, 24, 4176-4180. [CrossRef]

21. Spiegel, J.; Mas-Moruno, C.; Kessler, H.; Lubell, W.D. Cyclic Aza-peptide Integrin Ligand Synthesis and Biological Activity. J. Org. Chem. 2012, 77, 5271-5278. [CrossRef] [PubMed]

22. Isocyanate and/or hydantoin byproducts likely arise from activation of the resin-bound semicarbazide with the carbonyl donor, followed by intramolecular attack by the nitrogen of the preceding amino acid residue. See: Quibell, M.; Turnell, W.G.; Johnson, T., Synthesis of Azapeptides by the Fmoc Tert-Butyl Polyamide Technique. J. Chem. Soc. Perk. Trans 1 1993, 22, 2843-2849. [CrossRef]

23. Paradis-Bas, M.; Tulla-Puche, J.; Albericio, F. The road to the synthesis of "difficult peptides". Chem. Soc. Rev. 2016, 45, 631-654. [CrossRef]

24. Murray, J.K.; Farooqi, B.; Sadowsky, J.D.; Scalf, M.; Freund, W.A.; Smith, L.M.; Chen, J.D.; Gellman, S.H. Efficient synthesis of a beta-peptide combinatorial library with microwave irradiation. J. Am. Chem. Soc. 2005, 127, 13271-13280. [CrossRef]

25. Chingle, R.; Ratni, S.; Claing, A.; Lubell, W.D. Application of Constrained aza-Valine Analogs for Smac Mimicry. Biopolymers 2016, 106, 235-244. [CrossRef] [PubMed]

26. Arujoe, M.; Ploom, A.; Mastitski, A.; Jarv, J. Comparison of various coupling reagents in solid-phase aza-peptide synthesis. Tetrahedron Lett. 2017, 58, 3421-3425. [CrossRef]

27. Arujoe, M.; Ploom, A.; Mastitski, A.; Jarv, J. Influence of steric effects in solid-phase aza-peptide synthesis. Tetrahedron Lett. 2018, 59, 2010-2013. [CrossRef]

28. Beutner, G.L.; Young, I.S.; Davies, M.L.; Hickey, M.R.; Park, H.; Stevens, J.M.; Ye, Q.M. TCFH-NMI: Direct Access to N-Acyl Imidazoliums for Challenging Amide Bond Formations. Org. Lett. 2018, 20, 4218-4222. [CrossRef] [PubMed]

29. Devos, A.; Remion, J.; Frisquehesbain, A.M.; Colens, A.; Ghosez, L. Synthesis of Acyl Halides under Very Mild Conditions. J. Chem. Soc. Chem. Comm. 1979, 24, 1180-1181. [CrossRef]

30. Gibson, C.; Goodman, S.L.; Hahn, D.; Ho“lzemann, G.; Kessler, H. Novel Solid-Phase Synthesis of Azapeptides and Azapeptoides via Fmoc-Strategy and Its Application in the Synthesis of RGD-Mimetics. J. Org. Chem. 1999, 64, 7388-7394. [CrossRef]

31. Bourguet, C.B.; Sabatino, D.; Lubell, W.D. Benzophenone Semicarbazone Protection Strategy for Synthesis of Aza-Glycine Containing Aza-Peptides. Biopolymers 2008, 90, 824-831. [CrossRef] [PubMed] 
32. Chingle, R.; Mulumba, M.; Chung, N.N.; Nguyen, T.M.; Ong, H.; Ballet, S.; Schiller, P.W.; Lubell, W.D. Solid-Phase Azopeptide Diels-Alder Chemistry for Aza-Pipecolyl Residue Synthesis to Study Peptide Conformation. J. Org. Chem. 2019, 84, 6006-6016. [CrossRef] [PubMed]

33. Searle, M.S.; Griffiths-Jones, S.R.; Skinner-Smith, H. Energetics of weak interactions in a beta-hairpin peptide: Electrostatic and hydrophobic contributions to stability from lysine salt bridges. J. Am. Chem. Soc. 1999, 121, 11615-11620. [CrossRef]

34. Bouayad-Gervais, S.H.; Lubell, W.D. Examination of the potential for adaptive chirality of the nitrogen chiral center in aza-aspartame. Molecules 2013, 18, 14739. [CrossRef]

35. It should be noted that replacement of valine for an aza-glycine residue results in an overall decrease in chiral environment, which may affect diastereotopic glycine splitting.

36. Kiehna, S.E.; Waters, M.L. Sequence dependence of beta-hairpin structure: Comparison of a salt bridge and an aromatic interaction. Protein Sci. 2003, 12, 2657-2667. [CrossRef] [PubMed]

Sample Availability: Samples of the compounds are available from the authors.

(C) 2019 by the authors. Licensee MDPI, Basel, Switzerland. This article is an open access article distributed under the terms and conditions of the Creative Commons Attribution (CC BY) license (http://creativecommons.org/licenses/by/4.0/). 